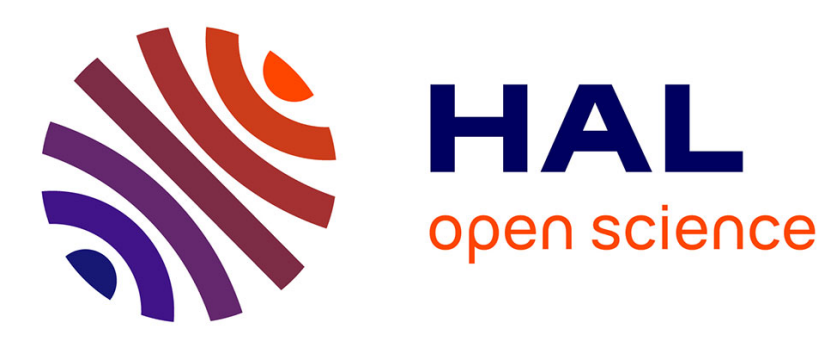

\title{
Novel KCNV2 mutations in cone dystrophy with supernormal rod electroretinogram.
}

Safouane Ben Salah, Satomi Kamei, Audrey Sénéchal, Séverine Lopez, Christian Bazalgette, Cécile Bazalgette, Claudie Malrieu Eliaou, Xavier Zanlonghi, Christian P. Hamel

\section{To cite this version:}

Safouane Ben Salah, Satomi Kamei, Audrey Sénéchal, Séverine Lopez, Christian Bazalgette, et al.. Novel KCNV2 mutations in cone dystrophy with supernormal rod electroretinogram.. American Journal of Ophthalmology, 2008, 145 (6), pp.1099-106. 10.1016/j.ajo.2008.02.004 . inserm-00259328

\section{HAL Id: inserm-00259328 https://www.hal.inserm.fr/inserm-00259328}

Submitted on 19 Jun 2008

HAL is a multi-disciplinary open access archive for the deposit and dissemination of scientific research documents, whether they are published or not. The documents may come from teaching and research institutions in France or abroad, or from public or private research centers.
L'archive ouverte pluridisciplinaire HAL, est destinée au dépôt et à la diffusion de documents scientifiques de niveau recherche, publiés ou non, émanant des établissements d'enseignement et de recherche français ou étrangers, des laboratoires publics ou privés. 
Purpose : To describe patients with cone dystrophy and supernormal rod electroretinogram and search for mutations in the recently described $K C N V 2$ gene.

Design : Clinical and molecular study

Methods : Patients from three families originating from France, Morocco and Algeria had standard ophthalmological examination and color vision analysis, Goldman perimetry, ISCEV ERG testing, autofluorescence evaluation and OCT-3 scanning. The two coding exons of $K C N V 2$ were PCR-amplified and sequenced.

Results : All patients had the characteristic features of supernormal, delayed rod ERG responses at the highest levels of stimulation and markedly reduced cone responses. In the French family, two affected sisters were compound heterozygotes for the recurrent c.1381G $>$ A (Gly461Arg) mutation and for a novel c.442G $>\mathrm{T}$ (Glu148Stop) mutation. In the Moroccan family, affected members were homozygotes for the novel c.1404delC mutation (His468fs X503) and in the Algerian family, the proband was homozygote for the novel c.1001delC mutation (Ala334fsX453). In the three families, parents were unaffected heterozygote carriers. None of the mutations were present in 50 control chromosomes.

Conclusions : The three novel truncative mutations are likely to be null mutations leading to loss of function, with no difference in the phenotype presentation. Amino acid changes are found exclusively in the $\mathrm{N}$-terminal fragment of the protein and in the P-loop, indicating the importance of those regions for the function of the KCNV2 protein. 